\title{
Inhibitory effect of 2-mercaptoethane sulfonate on the formation of Escherichia coli biofilms in vitro
}

\author{
SHENG CHEN ${ }^{1}$, NIANHAI HE ${ }^{1}$, JIALIN YU ${ }^{2}$, LUQUAN LI $^{2}$, FENGJUN SUN ${ }^{3}$, \\ YING HU ${ }^{1}$, RUI DENG ${ }^{1}$, SHIMING ZHONG ${ }^{1}$ and LEILEI SHEN ${ }^{1}$ \\ ${ }^{1}$ Department of Pediatrics, Southwest Hospital of The Third Military Medical University, Chongqing 400038; \\ ${ }^{2}$ Department of Neonatology, Children's Hospital of Chongqing Medical University, Chongqing 400014; \\ ${ }^{3}$ Department of Pharmacy, Southwest Hospital of The Third Military Medical University, Chongqing 400038, P.R. China
}

Received October 7, 2014; Accepted June 25, 2015

DOI: $10.3892 / \mathrm{mmr} .2015 .4112$

\begin{abstract}
The biofilms (BF) formed by Escherichia coli (E. coli) is an important cause of chronic and recurrent infections due to its capacity to persist on medical surfaces and indwelling devices, demonstrating the importance of inhibiting the formation of $E$. coli $\mathrm{BF}$ and reducing $\mathrm{BF}$ infection. Although 2-mercaptoethane sulfonate (MESNA) exhibits a marked mucolytic effect clinically, the effect of MESNA on the inhibition of $E$. coli $\mathrm{BF}$ formation remains to be elucidated. The present study investigated whether MESNA inhibits the formation of $E$. coli $\mathrm{BF}$ in vitro. The minimum inhibitory concentration of MESNA on E. coli was determined to be $10 \mathrm{mg} / \mathrm{ml}$. Subsequently, the effect of MESNA on BF early adhesion, extracellular polysaccharide (EPS) and extracellular protein were detected. The effect of a subinhibitory concentration of MESNA on BF formation was evaluated, and the inhibitory potency of MESNA against matured BF was assayed. The results revealed that MESNA inhibited early stage adhesion and formation of the E. coli $\mathrm{BF}$, destroyed the mature $\mathrm{BF}$ membrane and reduced the EPS and extracellular proteins levels of the BF. In addition, the present study investigated the effects of MESNA on the expression of EPS- and adhesion protein-associated genes using quantitative polymerase chain reaction analysis, which demonstrated that MESNA effectively inhibited the expression of these genes. These results suggested that MESNA possesses anti-BF formation capability on $E$. coli in vitro and may be used as a potential reagent for the clinical treatment of $E$. coli $\mathrm{BF}$-associated infections.
\end{abstract}

Correspondence to: Dr Nianhai He, Department of Pediatrics, Southwest Hospital of The Third Military Medical University, 30 Gaotanyan Street, Shapingba, Chongqing 400038, P.R. China E-mail: nianhaihe06@sina.com

Key words: biofilm, 2-mercaptoethane sulfonate, Escherichia coli, extracellular polymeric substances, gene expression

\section{Introduction}

Biomedical materials, including indwelling catheters, artificial joint replacements, heart valve replacements and tracheal intubation tubes, have been widely used in clinical practice, however, biomaterial-associated infection rates have increased each year, predominantly due to the formation of bacterial biofilm (BF) on the surface of the biomaterial $(1,2)$. Bacterial $\mathrm{BF}$ is a complex membrane structure comprising bacterial adhering to a solid surface. The BF can release planktonic bacteria constantly, resulting in repeated infections and novel BF formation. Following the formation of extracellular polymer secretion, drug resistance becomes 10-1,000 times higher, compared with that of free-floating bacteria (3). Several human bacterial infections are associated with BF, and antimicrobial therapy is often ineffective against BF (4). Therefore, it is essential to identify safe and effective agents for use against $\mathrm{BF}$ formation.

Escherichia coli (E.coli) is a common pathogen of urinary, respiratory and digestive system infections, and a frequent conditional pathogen of nosocomial infections (5). E. coli can attach to medical devices, including catheters or endotracheal intubation tubes, to cause associated chronic infections, and can also form BFs in bladder epithelial cells, resulting in persistent infection of the urinary tract $(6,7)$. Therefore, how the formation of $E$. coli BFs can be inhibited and the associated infections reduced is an urgent clinical problem, which requires resolution. Previous studies have revealed that numerous active sulfhydryl-containing compounds can inhibit $\mathrm{BF}$ formation. For example, $N$-acetylcysteine exhibits high potency in suppressing the BF formation of Pseudomonas aeruginosa, E. coli and Staphylococcus epidermidis (8-10), and dithiothreitol and $\beta$-mercaptoethanol can inhibit the BF formation of Staphylococcus aureus (11). In addition, certain widely used clinical mucolytic agents exhibit BF inhibitory capabilities. For example, our previous studies demonstrated that ambroxol, a secretolytic agent used in the treatment of respiratory diseases, effectively inhibits the BF formation of Pseudomonas aeruginosa $(12,13)$. The synthetic, small molecule compound, 2-mercaptoethane sulfonate (MESNA) is commonly used as a chemotherapeutic drug for hemorrhagic cystitis caused by cyclophosphamide and 
ifosfamide (14). MESNA is considered to be a clinically important mucolytic (15) and reducing agent (16). Its active sulfhydryl group (-SH) can form two disulfide polypeptide chains during sputum glycoprotein fracture, causing the decomposition and liquefaction of mucus glycoprotein, and DNA breakage. In addition, the mucolytic effect of MESNA has been reported to be more marked, compared with than that of $\mathrm{N}$-acetylcysteine (17). Although certain antibacterial peptides and nanomaterials are also potent inhibitors of BF formation $(18,19)$, the feasibility of their use in the majority of countries, particularly in developing countries, is limited due to its high cost, compared with MESNA (20). MESNA is used as a safe medicinal drug in the urinary system $(14,16)$, with high concentrations in the urine via either intravenous injection or oral administration (21). It may be a potential reagent for the treatment of urinary infection with $E$. coli $\mathrm{BF}$, however, the effects of MESNA on the inhibition of E. coli BF formation remains to be elucidated.

Extracellular polysaccharides (EPS) and extracellular proteins are the major components of $E$. coli extracellular polymers, which can affect bacterial adhesion and are important in maintaining the conformational space of biological membranes (22). E. coli adhesion protein-associated genes include $f i m H, f l u$ and $p a p C$, and EPS-associated genes include $g \operatorname{lm} S, \operatorname{glm} U, m s b B$ and $l p x A$. The present study hypothesized that MESNA may be a potent agent for the inhibition of E.coli $\mathrm{BF}$ formation, therefore, the present study was designed to systematically investigate the anti-biofilm capabilities of MESNA at different stages in vitro, including BF early adhesion, production of EPS and extracellular proteins, BF formation and destruction, downregulation of the expression of EPS-associated genes and adhesion protein-associated genes following MESNA treatment. The findings of these investigations may support the exploitation of MESNA as a promising and potent inhibitor against $E$. coli $\mathrm{BF}$ formation.

\section{Materials and methods}

Bacterial strains and reagents. E. coli ATCC 25922 was purchased from the National Institute for Food and Drug Control (Beijing, China). The bacteria were streaked out on Luria-Bertani agar (Sigma-Aldrich, St. Louis, MO, USA) from frozen stocks and subsequently inoculated into Luria-Bertani liquid medium (Sigma-Aldrich, St. Louis, MO, USA) for growth overnight at $37^{\circ} \mathrm{C}$ with agitation $(250 \mathrm{xg})$. MESNA was purchased from Sigma-Aldrich. A LIVE/DEAD ${ }^{\circledR}$ BacLight $^{\text {TM }}$ Staining kit containing SYTO $^{\circledR} 9$ and propidium iodide was purchased from Molecular Probes Life Technologies (Carlsbad, CA, USA). Phosphate-buffered saline (PBS; pH 7.4) was prepared in our molecular biology laboratory.

Detection of minimum inhibitory concentration (MIC). The MIC of MESNA was determined using a broth microdilution assay, according to Clinical and Laboratory Standards Institute Guidelines (23). Briefly, each well of a 96-well microtiter plate, containing a $100 \mu 1$ series of MESNA diluted with Mueller-Hintor broth (Beijing Land Bridge Technology Co., Beijing, China), was inoculated with $100 \mu 1 \mathrm{E}$. coli ATCC 25922. The final inoculum size was $5 \times 10^{5} \mathrm{CFU} / \mathrm{ml}$, and the final concentrations of MESNA were $0.078,0.156,0.313$,
$0.625,1.250,2.500,5.000,10.000,20.000$ and $40.000 \mathrm{mg} / \mathrm{ml}$. Following incubation in air at $35^{\circ} \mathrm{C}$ for $20 \mathrm{~h}$, the wells were inspected for microbial growth and the MIC was defined as the lowest concentration to inhibit the growth of bacteria. Positive (bacterial suspension) and negative (broth) controls were also included.

Early bacterial adhesion assay. When concentration of overnight cultured E. coli ATCC 25922 reached an optical density (OD) ${ }_{600}$ of 0.05 , measured using a spectrophotometer (UV-1700; Shimadzu Scientific Instruments, Suzhou, China), $100 \mu 1$ liquid bacteria was mixed with $100 \mu 1$ MESNA at concentrations of $0.0,0.5,2.0 \mathrm{or} 5.0 \mathrm{mg} / \mathrm{ml}$ in each well of sterilized medical polyvinyl chloride (PVC) plates (Yangzhou Kaier Chemical Co., Ltd., Jiangsu, China). Each sample was incubated for $2,4,6$ or $8 \mathrm{~h}$ at $37^{\circ} \mathrm{C}$. The PVC plates were rinsed with sterile PBS five times and sonicated for 20 min to allow the adhesive bacteria to shed. Suspensions of $0-, 10-, 100-$, $1,000-, 10,000-$, or 100,000-fold dilutions were smeared onto solid Luria-Broth medium. Colonies were counted by visual observation following culture at $37^{\circ} \mathrm{C}$ for $48 \mathrm{~h}$. All experiments were repeated six times in duplicate.

Extraction and determination of EPS and extracellular proteins. The production of extracellular polymeric substances from the bacterial surfaces was measured, as described previously (24) following incubation of the bacteria for $8 \mathrm{~h}$ at $37^{\circ} \mathrm{C}$, to reach the middle log phase, in MESNA at concentrations of $0.0,0.5,2.0$ or $5.0 \mathrm{mg} / \mathrm{ml} .10 \mathrm{ml}$ of cultured cells were centrifuged at $4,000 \mathrm{xg}$ and $4^{\circ} \mathrm{C}$ for $15 \mathrm{~min}$ to obtain a microbial floc, which was resuspended with distilled water to a total volume of $10 \mathrm{ml}$. Subsequently, $12 \mu \mathrm{l}$ formaldehyde (37\%) was added to the microbial floc, which was maintained at $4^{\circ} \mathrm{C}$ for $1 \mathrm{~h}$, followed by the addition of $0.8 \mathrm{ml} 1 \mathrm{~N} \mathrm{NaOH}$ at $4^{\circ} \mathrm{C}$ for $3 \mathrm{~h}$. The microbial floc solution was centrifuged again at $13.200 \mathrm{xg}$ at $4^{\circ} \mathrm{C}$ for $20 \mathrm{~min}$ to remove suspended solids prior to chemical component analysis. The concentrations of EPS and extracellular proteins in the extracted extracellular polymeric substances were determined according to phenol-sulfuric acid standard chromatography and the Bradford reagent method. The polysaccharide concentration was determined according to the phenol-sulfuric acid method with glucose as a standard by using chromatography at $490 \mathrm{~nm}(25)$. The protein concentration was determined using the Bradford reagent with bovine serum albumin as a standard, for which the dye had an absorption maximum at $595 \mathrm{~nm}$ (26).

$B F$ formation assay. To quantify the BF formation of E. coli in the absence and presence of MESNA, a microplate-based assay was performed, according to a previosly described method (27). Briefly, when the concentration of overnight-cultured E. coli ATCC 25922 reached a OD600 of 0.05 , measured using a spectrophotometer, $2.0 \mathrm{ml}$ liquid bacteria were added to a 24 -well plate with a $1 \times 1 \mathrm{~cm}$ silica gel plate (Shenzhen Hua Feng Li Plastic Products Co., Ltd., Guandong, China). Subsequently $2.0 \mathrm{ml}$ saline and MESNA solution at concentration of $0.5,2.0$ or $5.0 \mathrm{mg} / \mathrm{ml}$ were added to the 24-well plate. All mixtures were cultured at $37^{\circ} \mathrm{C}$, with the medium replaced every $12 \mathrm{~h}$. The morphology of BF was observed using a S-3400N scanning electron microscope 
Table I. Primer sequences used in the reverse transcription-quantitative polymerase chain reaction.

\begin{tabular}{|c|c|c|}
\hline Gene & Sequence $\left(5^{\prime}-3^{\prime}\right)$ & Product length (bp) \\
\hline Flu & $\begin{array}{l}\text { F: 5'-GGCGTTCACCAGGTTCAGGAT-3' } \\
\text { R: 5'-GGCAACCCTGAAAGTGAAAAACC-3' }\end{array}$ & 148 \\
\hline FimH & $\begin{array}{l}\text { F: 5'-GGCGGGGTGGCGATTAAAGC-3' } \\
\text { R: 5'-GAACCAGGGTAGTCCGGCAGAGT-3' }\end{array}$ & 188 \\
\hline PapC & $\begin{array}{l}\text { F: 5' -CCGGCCTTTTTCACTGGTTACAC-3' } \\
\text { R: 5' -GGCGGGCAGGTGGTGACAAAT-3' }\end{array}$ & 267 \\
\hline GlmS & $\begin{array}{l}\text { F: 5'-CTGGCTGGCCTGCGTCTGTC-3' } \\
\text { R: 5'-CGCCACCAGCATCAACAGCACA-3' }\end{array}$ & 186 \\
\hline$G \operatorname{lm} U$ & $\begin{array}{l}\text { F: 5'-TTTGCGTCCTGGTGCTGAGTTG-3' } \\
\text { R: 5'-GGTCGCGCCTTTGCCTACTGTTA- 3' }\end{array}$ & 268 \\
\hline$M s b B$ & $\begin{array}{l}\text { F: 5'-TGGCCGAATTTCAATAGTCAGGA-3' } \\
\text { R: 5'-TCGGGGGGCGCTTACATG-3' }\end{array}$ & 254 \\
\hline$I p x A$ & $\begin{array}{l}\text { F: 5'-GCGAACCGACCCGTGTGG-3' } \\
\text { R: 5'-GGCGAGAATACAGCGGTTACCT-3' }\end{array}$ & 173 \\
\hline$G A P D H$ & $\begin{array}{l}\mathrm{F}: \text { 5'-ACGCCAGCGACAAACTAATCA-3' } \\
\mathrm{R}: \text { 5'-CCCCCGCTGCTCTCGATTTAC-3' }^{\prime}\end{array}$ & 192 \\
\hline
\end{tabular}

F, forward; R, reverse.

(SEM; Hitachi, Ltd., Tokyo, Japan) following culture of the mixtures for $48 \mathrm{~h}$. The numbers of bacteria were counted, according to the bacterial colony counting method, described above.

BF destruction assay. Normal saline $(0.5 \mathrm{ml})$ and 2.0 or $5.0 \mathrm{mg} / \mathrm{ml}$ MESNA were added to the $E$. coli BF in six replicates. Planktonic bacteria were removed with PBS following incubation of the $\mathrm{BF}$ at $37^{\circ} \mathrm{C}$ for $6 \mathrm{~h}$. Then $\mathrm{BF}$ was then stained with SYTO propidium iodide LIVE/DEAD BacLight 9-bacterial stain, according to the manufacturer's instructions. The stained BFs were observed under a confocal laser scanning microscope (LSM 510 META; Zeiss, Wetzlan, Germany). Signals were recorded using green (excitation $488 \mathrm{~nm}$; emission 515/30 nm) and red (excitation $568 \mathrm{~nm}$; emission 600/50 nm) channels. Images were obtained using a layer-by-layer scan along the $\mathrm{Z}$-axis, with three repeated images for each group, three random visions for each image and 10-25 layers for each vision. Three-dimensional reconstruction of the images was then performed using Amira 5.2.1 software (Visage Imaging, San Diego, CA, USA) to observe morphological changes in the $E$. coli BF. Images were introduced to Image Structure Analyzer (ISA) 3D software, which was developed by Beyenal et al (28) to estimate structural parameters, including thickness, textual entropy (TE), areal porosity (AP; defined as the ratio of void area to the total area) and average diffusion distance (ADD; defined as the average of the minimum distance from each cluster pixel to the nearest void pixel over all clusters).

Reverse transcription-quantitative polymerase chain reaction $(R T-q P C R)$. The overnight-cultured bacteria were diluted in Luria-Broth medium (1:100) and allowed to grow to an $\mathrm{OD}_{600}$ of 0.05 . MESNA was added to the bacteria at a final concentration of $0.0,0.5,2.0$ or $5.0 \mathrm{mg} / \mathrm{ml}$ and incubated at $37^{\circ} \mathrm{C}$ for $2 \mathrm{~h}$. Total RNA was extracted from the bacterial pellet of $5 \mathrm{ml}$ cultured bacteria using A TRIzol ${ }^{\circledR}$ Plus RNA Kit (Biogenesis, Ltd., Poole, UK), according to manufacturer's instructions. RT-qPCR was performed using a qRT-PCR kit (Toyobo Co., Ltd., Tokyo, Japan), according to the manufacturer's instructions, in a CFX96 Real Time system (Bio-Rad Laboratories, Hercules, CA, USA) and primers were synthesized by Jie Rui Industrial, Co., Ltd. (Shanghai, China). The reaction system $(20 \mu \mathrm{l})$ contained 2X SYBR Green Master Mix (10 $\mu \mathrm{l})$, primer solution $(0.3 \mu \mathrm{l})$, cDNA $(2 \mu \mathrm{l})$ and $\mathrm{ddH}_{2} \mathrm{O}(7.4 \mu \mathrm{l})$. The reaction procedure involved incubation at $94^{\circ} \mathrm{C}$ for $5 \mathrm{~min}$ and 40 cycles of $94^{\circ} \mathrm{C}$ for $30 \mathrm{sec}, 57^{\circ} \mathrm{C}$ for $30 \mathrm{sec}$ and $72^{\circ} \mathrm{C}$ for $30 \mathrm{sec}$. The PCR products were run on a $1.0 \%$ agarose gel. Expression levels of the fimH, flu, papC, glmS, glmU, msbB and $l p x A$ genes were detected using RT-qPCR in triplicate. Quantitative data analysis was completed using an Eppendorf Mastercycler Real-time PCR system (Biometra GmbH, Goettingen, Germany). The $\Delta$ cycle threshold (CT) was defined as the CT values of each group - CT values of the corresponding glyceraldehyde 3-phospate dehydrogenase (Gapdh). The variance of gene expression was determined using the $2^{-\Delta \Delta \mathrm{CT}}$ equation. The primer sequences used are listed in Table I.

Statistical analysis. All data were analyzed using SPSS v.17.0 (SPSS, Inc., Chicago, IL, USA). The data are expressed as the mean \pm standard deviation. Comparisons between different groups was performed using one-way analysis of variance, and multiple comparisons were performed using homogeneity of variance analysis. $\mathrm{P}<0.05$ was considered to indicate a statistically significant difference. 


\section{Results}

MIC of MESNA towards E. coli. To determinate the MIC of MESNA towards $E$. coli, the $E$. coli cells were incubated with a gradient of increasing concentrations of MESNA between 0.078 and $40.000 \mathrm{mg} / \mathrm{ml}(0.078,0.156,0.313,0.625,1.250$, $2.500,5.000,10.000,20.000$ and $40.000 \mathrm{mg} / \mathrm{ml})$. The results revealed that MESNA at $10.000 \mathrm{mg} / \mathrm{ml}$ completely inhibited the growth of $E$. coli, indicating that the MIC value of MESNA towards E. coli ATCC 25922 was $10.000 \mathrm{mg} / \mathrm{ml}$. Therefore, the concentration of MESNA used for investigating the inhibitory of MESNA in BF formation was $<10 \mathrm{mg} / \mathrm{ml}$, as this was sublethal to E. coli.

Effects of MESNA on cell adhesion. In the present study, the number of adhering cells increased with bacterial cell aggregation. MESNA induction caused cell aggregation in a dose-dependent manner. The inoculum size for each well was $5 \times 10^{5} \mathrm{CFU} / \mathrm{ml}$. The total quantity of adhering bacteria treated with $0.5,2.0$ or $5.0 \mathrm{mg} / \mathrm{ml}$ of MESNA increased significantly, compared with the untreated bacteria $(\mathrm{P}<0.05$; Fig. 1$)$. Compared with the untreated group, the number of adherent bacteria increased in a gradients following treatment with 0.5 , 2.0 and $5.0 \mathrm{mg} / \mathrm{ml}$ MESNA for $2 \mathrm{~h}(15.35,31.54$ and $51.87 \%$, respectively), $4 \mathrm{~h}(13.89,25.62$ and $38.89 \%$, respectively) $6 \mathrm{~h}$ (12.57, 24.87 and $24.87 \%$, respectively) and $8 \mathrm{~h}(9.32,27.54$ and $38.30 \%$, respectively). These results indicated that the inhibitory effect increased with increasing concentrations of MESNA.

Effects of MESNA on EPS and extracellular proteins. The EPS of bacteria/bacterial dry weight $(\mathrm{g} / \mathrm{mg}$ ) was assessed to describe the production of EPS and extracellular proteins. When the bacteria from the microbial floc were treated with $0.5,2.0$ or $5.0 \mathrm{mg} / \mathrm{ml}$ MESNA, the level of EPS decreased significantly by $22.28,62.02$ and $67.87 \%$, respectively (Fig. 2); and the level of extracellular proteins decreased significantly by $24.54,66.71$ and $72.42 \%$, respectively (Fig. 2), compared with the untreated group.

Inhibition of MESNA on E. coli BF formation. Images of the $E$. coli BF were captured under SEM. The BF of the untreated $(0.0 \mathrm{mg} / \mathrm{ml}$ MESNA) bacteria group was thicker and denser, with thick and large mucoid materials wrapping outside (Fig. 3A); the $\mathrm{BF}$ of the $0.5 \mathrm{mg} / \mathrm{ml}$ MESNA-treated bacteria was thinner and contained fewer mucus substances (Fig. 3B). Compared with the untreated or $0.5 \mathrm{mg} / \mathrm{ml} \mathrm{MESNA-treated} \mathrm{groups,} \mathrm{the}$ BF became markedly thinner and the mucus substances were lower in the $2.0 \mathrm{mg} / \mathrm{ml} \mathrm{MESNA-treated} \mathrm{group} \mathrm{(Fig.} \mathrm{3C).} \mathrm{The}$ $5.0 \mathrm{mg} / \mathrm{ml}$ MESNA-treated bacteria group was almost scattered with rare myxoid material and contained no agglomerated bacteria (Fig. 3D). Compared with the untreated group, the survival of the E. coli decreased by $9.21,25.24$ and $49.84 \%$ when treated with $0.5,2.0$ and $5.0 \mathrm{mg} / \mathrm{ml}$ MESNA, respectively (Fig. 4). These results demonstrated that MESNA exhibited a negative role on $E$. coli $\mathrm{BF}$ formation, and the survival number of $E$. coli in the BF decreased significantly following treatments with increasing concentrations of MESNA $(\mathrm{P}<0.05)$.

Destructive effect of MESNA on the matured E. coli BF. The appearance of bacteria in the $E$. coli $\mathrm{BF}$ were more dense and

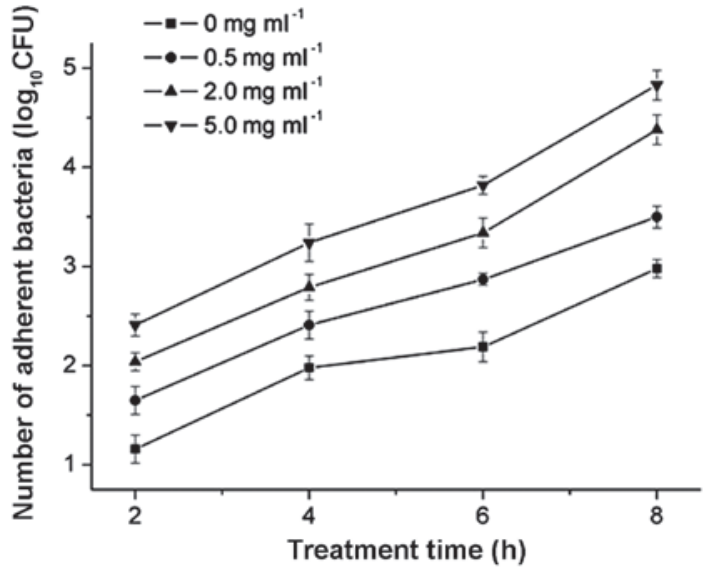

Figure 1. Number of adhering cells ( $\log _{10} \mathrm{CFU} / \mathrm{chip}$ ) treated with 0.0, 0.5, 2.0 or $5.0 \mathrm{mg} / \mathrm{ml}$ 2-mercaptoethane sulfonate. All data are expressed as the mean \pm standard deviation from six independent culture batches.

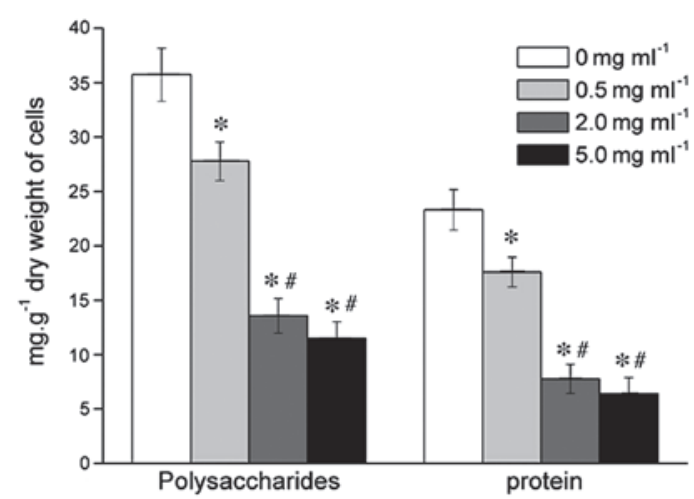

Figure 2. MESNA decreases the production of extracellular polysaccharides and extracellular proteins following treatment with or without MESNA (0.5, 2.0 or $5.0 \mathrm{mg} / \mathrm{ml}) .{ }^{*} \mathrm{P}<0.05$ compared with the untreated $(0 \mathrm{mg} / \mathrm{ml})$ group; ${ }^{\#} \mathrm{P}<0.05$, compared with the $0.5 \mathrm{mg} / \mathrm{ml}$ group. Data are expressed as the mean \pm standard deviation. MESNA, 2-mercaptoethane sulfonate.

BF bulges were larger without MESNA treatment (Fig. 5A). The thickness of the BF treated with $2.0 \mathrm{mg} \mathrm{ml}^{-1}$ MESNA was decreased (Fig. 5B) and the BF density was more sparse, compared with the untreated samples. The thickness of the $\mathrm{BF}$, treated with $5.0 \mathrm{mg} / \mathrm{ml}$ MESNA was reduced even further and was more sparse (Fig. 5C). The ISA quantitative analysis demonstrated that treatments with either 2.0 or $5.0 \mathrm{mg} / \mathrm{ml}$ decreased the thickness of the $E$. coli $\mathrm{BF}$. Compared with the untreated group (thickness, $18.11 \pm 2.43 \mu \mathrm{m}$ ), when the BF was treated with $2.0 \mathrm{mg} / \mathrm{ml}$ and $5.0 \mathrm{mg} / \mathrm{ml} \mathrm{MESNA}$, the thickness reduced significantly by $59.97 \%(7.25 \pm 2.15 \mu \mathrm{m})$ and $72.0 \%$ $(5.07 \pm 1.62 \mu \mathrm{m})$, respectively $(\mathrm{P}<0.05$; Fig. $6 \mathrm{~A})$, and the AP increased by 27.78 and $33.33 \%$, respectively ( $P<0.05$; Fig. 6B). When the BF was treated with $5.0 \mathrm{mg} / \mathrm{ml}$ MESNA, the ADD and TE decreased by 36.69 and $26.81 \%$, respectively $(\mathrm{P}<0.05$; Fig. 6C and D).

RT-qPCR detection of the expression levels of FimH, Flu, PapC, GlmS, GlmU, MsbB and LpxA. Following treatment of the $E$. coli liquid bacteria with MESNA at concentrations of $0.5,2.0$ and $5.0 \mathrm{mg} / \mathrm{ml}$, the expression levels of the FimH, Flu, $P a p C, G \operatorname{lm} S, G \operatorname{lm} U, M s b B$ and $L p x A$ genes, with the exception 


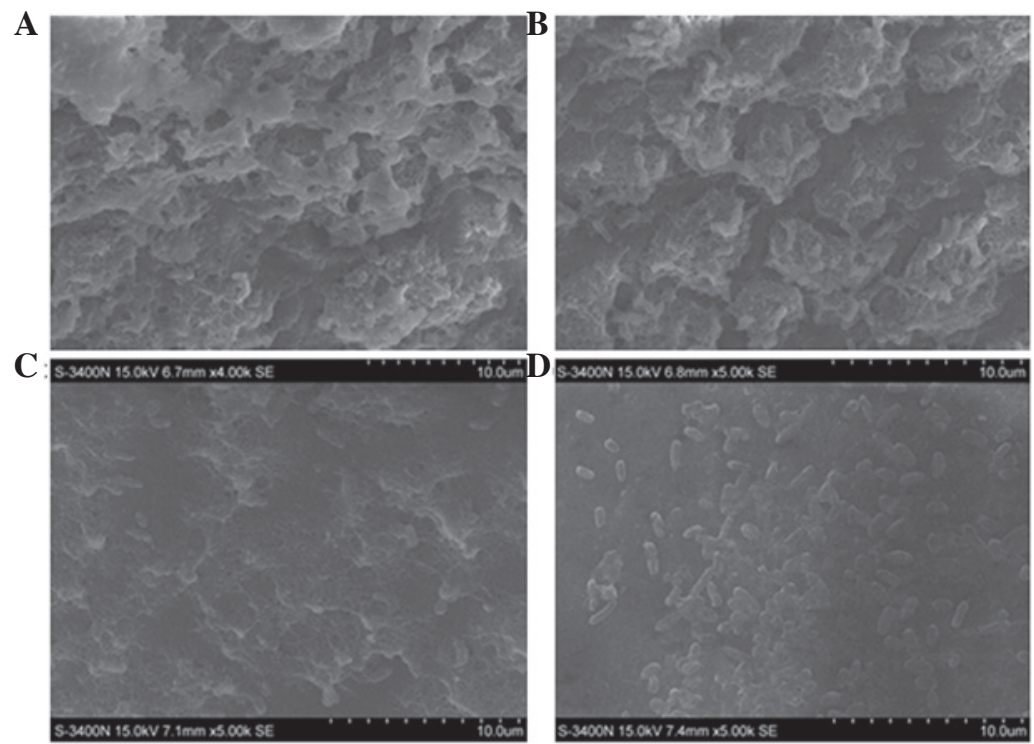

Figure 3. Scanning electron micrograph image of Escherichia coli ATCC 25922 BF (A) without MESNA (magnification, x4,000) and with (B) $0.5 \mathrm{mg} / \mathrm{ml}$ MESNA (magnification, x5,000), (C) $2.0 \mathrm{mg} / \mathrm{ml}$ MESNA (magnification, x5,000) and (D) $5.0 \mathrm{mg} / \mathrm{ml} \mathrm{MESNA} \mathrm{(magnification,} \mathrm{x5,000).} \mathrm{BF,} \mathrm{biofilm;} \mathrm{MESNA,}$ 2-mercaptoethane sulfonate.

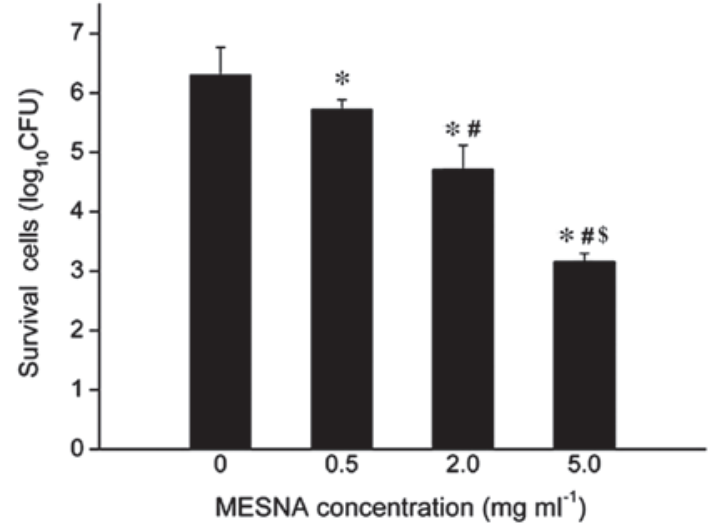

Figure 4. Number of surviving bacterial cells in the BF of Escherichia coli ATCC 25922 following treatment with of without MESNA $(0.5,2.0$ or $5.0 \mathrm{mg} / \mathrm{ml}) .{ }^{*} \mathrm{P}<0.05$, compared with the untreated $(0.0 \mathrm{mg} / \mathrm{ml}$ MESNA) group; ${ }^{\$} \mathrm{P}<0.05$, compared with the $0.5 \mathrm{mg} / \mathrm{ml}$ MESNA group; ${ }^{*} \mathrm{P}<0.05$, compared with the $2.0 \mathrm{mg} / \mathrm{ml}$ MESNA group. BF, biofilm; MESNA, 2-mercaptoethane sulfonate.

of $l p x A$ in the $0.5 \mathrm{mg} / \mathrm{ml}$-treated group, were suppressed $(\mathrm{P}<0.05)$, compared with the mock-treated group. The expression levels of the majority of genes decreased with MESNA at concentrations of 2.0 and $5.0 \mathrm{mg} / \mathrm{ml}$ (Fig. 7).

\section{Discussion}

To identify an effective agent to inhibit the formation of E. coli $\mathrm{BF}$, the present study investigated the MIC of MESNA and then evaluated the effects of subinhibitory concentrations of MESNA on the E. coli $\mathrm{BF}$ through observation of its effects on bacterial adhesion, and BF formation and destruction. The mechanism underlying the action of MESNA on the inhibition of $\mathrm{BF}$ formation was also investigated by detecting the expression levels of the FimH, Flu and PapC adhesion protein-associated genes and the $G \operatorname{lm} S, G \operatorname{lm} U, M s b B$ and

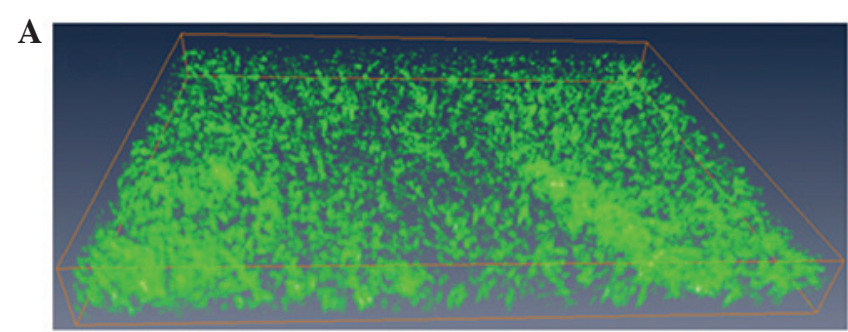

B
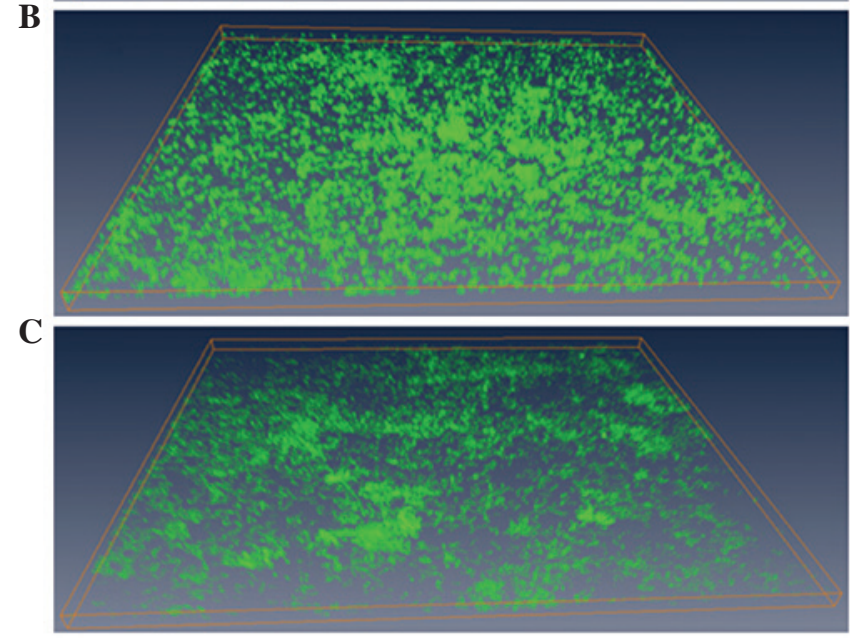

Figure 5. Confocal laser scanning microscope images of MESNA-treated or mock-treated samples. (A) MESNA at $0.0 \mathrm{mg} / \mathrm{ml}$; (B) MESNA at $2.0 \mathrm{mg} / \mathrm{ml}$; (C) MESNA at $5.0 \mathrm{mg} / \mathrm{ml}$. MESNA, 2-mercaptoethane sulfonate.

LpxA EPS-associated genes. The results demonstrated that the MIC to E. coli ATCC 25922 was $10.000 \mathrm{mg} / \mathrm{ml}$, and MESNA at subinhibitory concentrations inhibited the formation of E. coli $\mathrm{BF}$ and destroyed the BF. The mechanism of the inhibitory effects of MESNA may be that MESNA inhibited the expression of EPS-associated genes and adhesion protein-associated genes. In addition MESNA may inhibit the production of EPS and extracellular proteins by breaking down disulfide bonds. Notably, in the present study, 
A

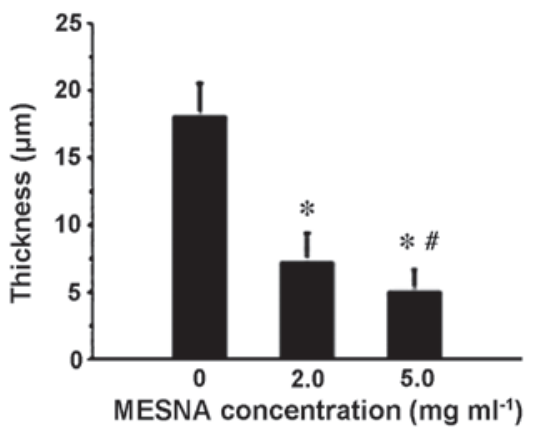

C

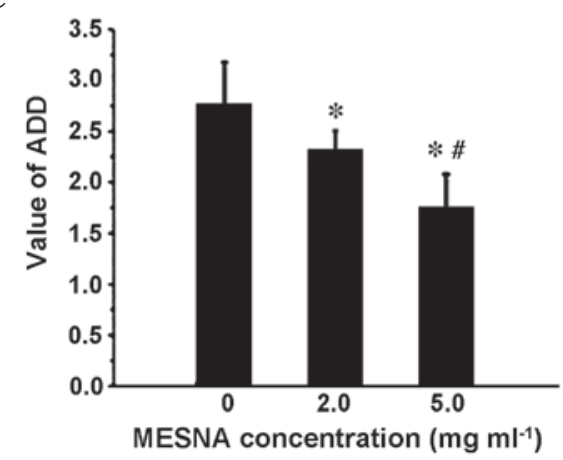

B

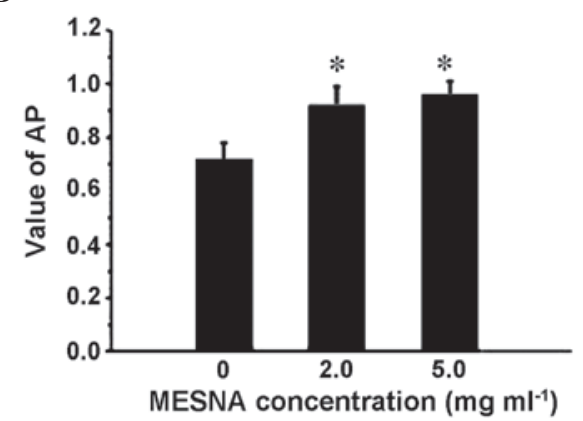

D

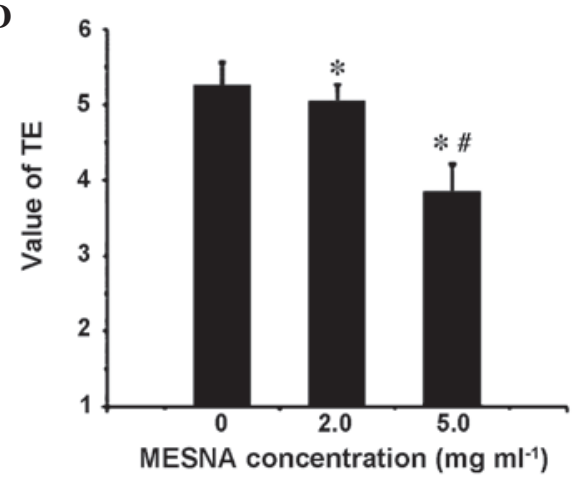

Figure 6. Comparison of characteristics of Escherichia coli ATCC $25922 \mathrm{BF}$ following treatment with or without MESNA (2.0 or 5.0 mg/ml). Images were captured under a confocal laser scanning microscope and analyzed using ISA software. (A) Average thickness. (B) AP. (C) ADD. (D) TE. Data are presented as the mean of three image stacks collected from randomly-selected areas \pm standard deviation. * $\mathrm{P}<0.05$, compared with the untreated $(0.0 \mathrm{mg} / \mathrm{ml})$ group; ${ }^{\#} \mathrm{P}<0.05$, compared with the $2.0 \mathrm{mg} / \mathrm{ml}$ group. BF, biofilm; MESNA, 2-mercaptoethane sulfonate; AP, areal porosity; ADD, average diffusion distance; TE, textual entropy.

$2 \mathrm{mg} / \mathrm{ml}$ MESNA reduced the levels of the E. coli BF EPS and extracellular proteins to 62.02 and $66.7 \%$, respectively, while $N$-acetylcysteine at the same concentration has been observed to reduce the exopolysaccharide matrix of the $\mathrm{BF}$ of four E. coli strains to between 25 and 68\% (9), suggesting that MESNA can achieve similar inhibitory effects on BF formation as $N$-acetylcysteine.

The adhering and BF-forming abilities of $E$. coli decreased following previous treatment with subinhibitory concentrations of MESNA (Figs. 1,3 and 4), and MESNA at subinhibitory concentrations destroyed the formed BF (Figs. 5 and 6). Quantitative and qualitative CLSM and ISA3D image analysis were also performed to demonstrate the effect of MESNA on the obstruction of E. coli BF maturation. The thickness and ADD of the E. coli BF decreased, while the AP increased. AP and ADD are two parameters, which can directly describe the characteristics of BF structure and nutrient supply (28). The results indicated that the BF became more sparse, the size of the channels among the colonies increased and the nutrient supplying distance was shortened following MESNA treatment. Considering that TE is a reflection of BF homogeneity index (28), and the BF homogeneity and uniformity were reduced by MESNA treatmen, it can be concluded that MESNA may have a destructive effect on maturation of E. coli BFs.

The expression levels of the $\mathrm{fimH}, \mathrm{flu}$ and papC adhesion protein-associated genes and the $g \operatorname{lm} S, g \operatorname{lm} U, m s b B$ and $\operatorname{lp} x A$ EPS-associated genes were significantly reduced following MESNA treatment (Fig. 7). Therefore, the inhibitory effects of MESNA on the E. coli BF may be through inhibiting the expression of these genes. The Flu gene encodes Ag43, which

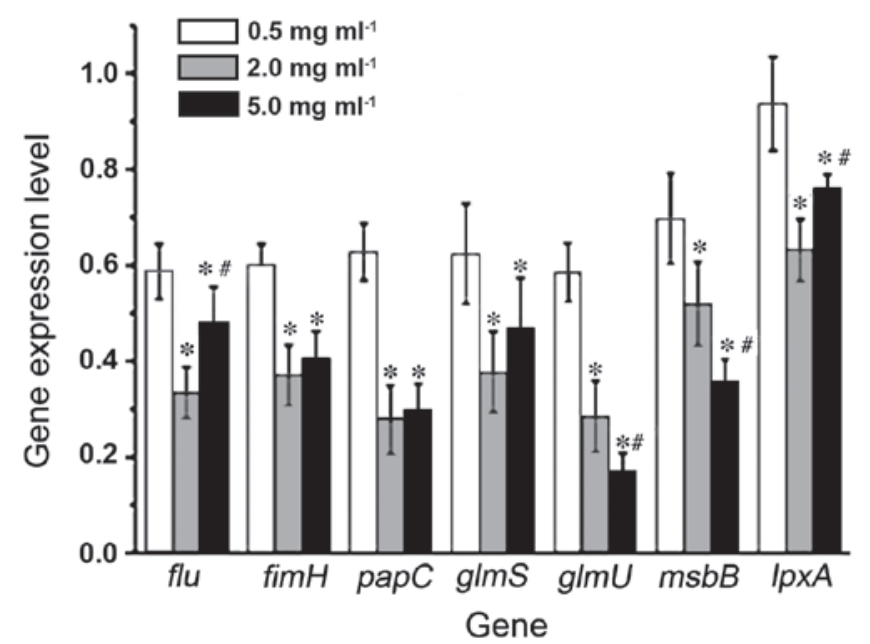

Figure 7. Relative gene expression levels as the ratio of gene expression in the MESNA-treated group to the mock-treated group. ${ }^{*} \mathrm{P}<0.05$, compared with the $0.5 \mathrm{mg} / \mathrm{ml}$ group; ${ }^{\#} \mathrm{P}<0.05$, compared with the $2.0 \mathrm{mg} / \mathrm{ml}$ group. MESNA, 2-mercaptoethane sulfonate.

is a transcriptional regulation protein that is involved in $E$. coli secretion and mediates the adhesion, invasion, long-term colonization and formation of $\mathrm{BF}(29,30)$. The expression of $\mathrm{Ag} 43$ is predominantly regulated by OxyR. Ulett et al (29) used the dithiothreitol reducing agent to reduce $E$. coli $\mathrm{BF}$ formation, and found that the expression of the Ag43-encoding Flu gene was reduced. MESNA is not only an important mucus solvent, but is also a reducing agent, and the present study hypothesized that the inhibitory effect of MESNA on the expression of the 
Flu gene expression is associated with the competitive or non-competitive inhibition of enzymes containing sulfhydryl in bacteria. FimH exists in the end of I pilus, which is the predominant adhesion factor in the type I pili of $E$. coli. This bacterium can identify the host cell surface-mannose through the I pilus to attach. FimH not only mediates the formation of E. coli $\mathrm{BF}$ in vitro, but it also promotes the formation of $\mathrm{BF}$ in cells $(7,31)$. The present study hypothesized that MESNA may inhibit the expression of the FimH gene, and thus reduces the production of certain enzymes associated with the formation of BF. The present study also demonstrated that MESNA inhibited the expression of the PapC gene. Notably, the $P a p C$ gene is an important gene encoding $\mathrm{P}$ fimbriae and an important virulence factor contributing to the formation of BF (32). Uridine diphosphate $\mathrm{N}$-acetylglucosamine (UDP-GlcNac) is the basic material of $E$. coli BF polysaccharides $(33,34)$. NsgB and GlmS are important catalytic enzymes of mutual transformation in sugar amine metabolism of glucose 6-phosphate and fructose 6-biphosphate, which is the first and rate-limiting step of hexaose biosynthesis. GlmU exhibits 1-phosphoglucosamine acetyltransferase and $\mathrm{N}$-acetyl-glucosamine 1-phosphate uridyl transferase activity, which is the most important enzyme to catalyze the formation of UDP-GlcNac. The $M s b B$-encoding product mediates peptidoglycan production (35), and the LpxA gene-encoding product mediates endotoxin formation. Therefore, expression of the downstream $M s b B$ and $L p x A$ genes are also associated with the formation of UDP-GlcNac (36). Therefore, MESNA inhibited the production of various adhesion proteins and EPS to affect the formation of the E. coli BF.

The present study demonstrated that MESNA exhibited inhibitory effects on the formation of the E. coli BF in vitro. These findings offer support for further investigations of MESNA on the formation of E. coli BF in vivo, and may eventually lead to either an effective clinical treatment or cure for $E$. coli infection with BF formation in the future.

\section{Acknowledgements}

The authors would thank to Professor Wang Ning and Professor Zhao Kecen at the Southwest Hospital of the Third Military Medical University (Chongqing, China), the Central Laboratory of the Experimental Medicine Division of the Southwest Hospital of The Third Military Medical University, and associate Professor Ju Lu of the Electron Microscopy Laboratory of the Third Military Medical University for their assistance with the experiments. The authors would also like to thank Professor Haluk Beyenal of American Montana State University (Bozeman, MT, USA) for providing ISA3D software. This study was supported by the National Natural Science Foundation of China (grant. nos. 30772363 and 30901279).

\section{References}

1. Arciola CR: New concepts and new weapons in implant infections. Int J Artif Organs 32: 533-536, 2009.

2. Vasilev K, Cook J and Griesser HJ: Antibacterial surfaces for biomedical devices. Expert Rev Med Devices 6: 553-567, 2009.

3. Høiby N, Bjarnsholt T, Givskov M, Molin S and Ciofu O: Antibiotic resistance of bacterial biofilms. Int J Antimicrob Agents 35: 322-332, 2010.
4. Lopes SP, Ceri H, Azevedo NF and Pereira MO: Antibiotic resistance of mixed biofilms in cystic fibrosis: Impact of emerging microorganisms on treatment of infection. Int $\mathrm{J}$ Antimicrob Agents 40: 260-263, 2012.

5. Tao XB, Qian LH, Li Y, Wu Q, Ruan JJ, Cai DZ and Peng H: Hospital-acquired infection rate in a tertiary care teaching hospital in China: A cross-sectional survey involving 2434 inpatients. Int J Infect Dis. 27: 7-9, 2014.

6. Anderson GG, Palermo JJ, Schilling JD, Roth R, Heuser J and Hultgren SJ: Intracellular bacterial biofilm-like pods in urinary tract infections. Science 301: 105-107, 2003.

7. Berry RE, Klumpp DJ and Schaeffer AJ: Urothelial cultures support intracellular bacterial community formation by uropathogenic Escherichia coli. Infect Immun 77: 2762-2772, 2009.

8. Zhao T and Liu Y: N-acetylcysteine inhibit biofilms produced by Pseudomonas aeruginosa. BMC Microbiol 10: 140, 2010.

9. Marchese A, Bozzolasco M, Gualco L, Debbia EA, Schito GC and Schito AM: Effect of fosfomycin alone and in combination with $\mathrm{N}$-acetylcysteine on $E$. coli biofilms. Int J Antimicrob Agents 22: 95-100, 2003.

10. Leite B, Gomes F, Teixeira P, Souza C, Pizzolitto E and Oliveira R: Staphylococcus epidermidis biofilms control by $\mathrm{N}$-acetylcysteine and rifampicin. Am J Ther 20: 322-328, 2013.

11. Wu X, Wang Y and Tao L: Sulfhydryl compounds reduce Staphylococcus aureus biofilm formation by inhibiting PIA biosynthesis. FEMS Microbiol Lett 316: 44-50, 2011.

12. Lu Q, Yu J, Yang X, Wang J, Wang L, Lin Y and Lin L: Ambroxol interferes with Pseudomonas aeruginosa quorum sensing. Int J Antimicrob Agents 36: 211-215, 2010.

13. Li F, Wang W, Hu L, Li L and Yu J: Effect of ambroxol on pneumonia caused by Pseudomonas aeruginosa with biofilm formation in an endotracheal intubation rat model. Chemotherapy 57: 173-180, 2011.

14. Kyung YS, Park HY and Lee G: Preservation of uroplakins by 2-mercaptoethanesulfonate in cyclophosphamide-induced rat cystitis. Arch Toxicol 85: 51-57, 2011.

15. Casale M, Di Martino A, Salvinelli F, Trombetta M and Denaro V: MESNA for chemically assisted tissue dissection. Expert Opin Investig Drugs 19: 699-707, 2010.

16. Ludwig U,Riedel MK, Backes M,Imhof A, Muche R and Keller F: MESNA (sodium 2-mercaptoethanesulfonate) for prevention of contrast medium-induced nephrotoxicity-controlled trial. Clin Nephrol 75: 302-308, 2011

17. Tekeres M, Horváth A, Bárdosi L and Kenyeres P: Clinical studies on the mucolytic effect of mesna. Clin Ther 4: 56-60, 1981.

18. Hou S, Liu Z, Young AW, Mark SL, Kallenbach NR and Ren D: Effects of Trp- and Arg-containing antimicrobial-peptide structure on inhibition of Escherichia coli planktonic growth and biofilm formation. Appl Environ Microbiol 76: 1967-1974, 2010.

19. Evliyaoğlu Y, Kobaner M, Celebi H, Yelsel K and Doğan A: The efficacy of a novel antibacterial hydroxyapatite nanoparticle-coated indwelling urinary catheter in preventing biofilm formation and catheter-associated urinary tract infection in rabbits. Urol Res 39: 443-449, 2011.

20. Tran N and Tran PA: Nanomaterial-based treatments for medical device-associated infections. Chemphyschem 13: 2481-2494, 2012.

21. Goren MP, Houle JM, Bush DA, Li JT, Newman CE and Brade WP: Similar bioavailability of single-dose oral and intravenous mesna in the blood and urine of healthy human subjects. Clin Cancer Res 4: 2313-2320, 1998.

22. Flemming $\mathrm{HC}$ and Wingender $\mathrm{J}$ : The biofilm matrix. Nat Rev Microbiol 8: 623-633, 2010.

23. Wayne, PA: Clinical and laboratory standards institute performance standards for antimicrobial susceptibility testing: Eighteenth informational supplement. CLSI document M100-S18. USA, 2008.

24. Wu B, Wang Y, Lee YH, Horst A, Wang Z, Chen DR, Sureshkumar R and Tang YJ: Comparative eco-toxicities of nano-ZnO particles under aquatic and aerosol exposure modes. Environ Sci Technol 44: 1484-1489, 2010.

25. Saha SK and Brewer CF: Determination of the concentrations of oligosaccharides, complex type carbohydrates and glycoproteins using the phenol-sulfuric acid method. Carbohydr Res 254: 157-167, 1994.

26. Bradford MM: A rapid and sensitive method for the quantitation of microgram quantities of protein utilizing the principle of protein-dye binding. Anal Biochem 72: 248-254, 1976. 
27. Strathmann M, Wingender J and Flemming HC: Application of fluorescently labelled lectins for the visualization and biochemical characterization of polysaccharides in biofilms of Pseudomonas aeruginosa. J Microbiol Methods 50: 237-248, 2002.

28. Beyenal H, Donova C, Lewandowski Z and Harkin G: Three-dimensional biofilm structure quantification. J Microbiol Methods 59: 395-413, 2004.

29. Ulett GC, Valle J, Beloin C, Sherlock O, Ghigo JM and Schembri MA: Functional analysis of antigen 43 in uropathogenic Escherichia coli reveals a role in long-term persistence in the urinary tract. Infect Immun 75: 3233-3244, 2007.

30. Naves P, del Prado G, Huelves L, Gracia M, Ruiz V, Blanco J, Dahbi G, Blanco M, Ponte Mdel C and Soriano F: Correlation between virulence factors and in vitro biofilm formation by Escherichia coli strains. Microb Pathog 45: 86-91, 2008.

31. Schembri MA and Klemm P: Biofilm formation in a hydrodynamic environment by novel fimh variants and ramifications for virulence. Infect Immun 69: 1322-1328, 2001.
32. Tiba MR, Nogueira GP and Leite Dda S: Study on virulence factors associated with biofilm formation and phylogenetic groupings in Escherichia coli strains isolated from patients with cystitis. Rev Soc Bras Med Trop 42: 58-62, 2009 (In Portuguese).

33. Itoh Y, Rice JD, Goller C, Pannuri A, Taylor J, Meisner J, Beveridge TJ, Preston JF III and Romeo T: Roles of pgaABCD genes in synthesis, modification and export of the Escherichia coli biofilm adhesin poly-beta-1,6- $N$-acetyl-D-gluc osamine. J Bacteriol 190: 3670-3680, 2008.

34. Suman E, D'souza SJ, Jacob P, Sushruth MR and Kotian MS: Anti-biofilm and anti-adherence activity of Glm-U inhibitors. Indian J Med Sc 65: 387-392, 2011.

35. Yeom J, Lee Y and Park W: Effects of non-ionic solute stresses on biofilm formation and lipopolysaccharide production in Escherichia coli O157:H7. Res Microbiol 163: 258-267, 2012.

36. Ulaganathan V, Buetow L and Hunter WN: Nucleotide substrate recognition by UDP-N-acetylglucosamine acyltransferase (LpxA) in the first step of lipid A biosynthesis. J Mol Biol 369: 305-312, 2007. 